\title{
A Weibull Method for Investigating Flashover Voltage of Outdoor Polymer Insulators
}

\author{
El-Said A. Othman ${ }^{1}$, L.S. Nasrat ${ }^{2}$, AbdelrahmanA. Z. Saleh ${ }^{3}$ \\ Professor, Electrical Power and Machine Department, Faculty of Engineering, Alazhar University, Cairo, Egypt ${ }^{1}$ \\ Professor, Electrical Power and Machine Department, Faculty of Engineering, Aswan University, Aswan, Egypt ${ }^{2}$ \\ Ph.D. Researcher, Electrical Power and Machine Dept, Faculty of Engineering, Alazhar University, Qena, Egypt ${ }^{3}$
}

\begin{abstract}
Adding inorganic fillers to unsaturated polyester helps to greatly improve the electrical properties of polymer insulating materials according to the percentage of fillers concentrations and the types of fillers. Experiments and measurements have been performed to study and analyse the flashover voltage of unsaturated polyester with alumina trihydrate ATH and mica fillers with variety of samples lengths at different weather conditions. The probability of flashover to occur has been studied in this research. Flashover voltage value at dry unfilled polyester was $23.2 \mathrm{KV}$ at $2.0 \mathrm{~cm}$ sample length. Polyester with ATH filler at $60 \mathrm{wt} \%$ concentration reached the greatest value of flashover voltage 42.3 KV at the same sample length. Polyester with mica filler achieved good results but the maximum percentage of mica filler concentration to be added was $40 \mathrm{wt} \%$ with flashover voltage value of $38.4 \mathrm{KV}$.
\end{abstract}

Keywords: Flashover, Polymer, Insulators, Outdoor, High Voltage.

\section{INTRODUCTION}

In New Qena City and all new cities the polymer Polyester has excellent dielectric and electrical properties insulating materials used in outdoor insulators and high as polymers high voltage insulating materials, ultrasonic voltage transmission lines should have excellent techniques used to study and analyse the effect of type and electrical properties; this is for the best operation of the concentration of silica ( $\mathrm{SiO} 2)$ and Alumina Trihydrate electrical components as in the recent years the polymer [ATH] fillers to improve the electrical properties of insulating materials have been developed greatly. polyester composite [4].

Flashover studies for polyster insulating materials and The study of adding ATH filler to Ethylene Propylene polyster composites insulators have been prepared with Diene Monomer (EPDM) which is used as outdoor different environmental and climate conditions. Fillers insulating material using Ultra Violet (UV) radiation has with different concentrations used to improve the been prepared that will cause improvement in its electrical, mechanical and thermal properties are alumina properties by exposure to ultraviolet (UV) radiation [5].

trihydrate [ATH], boric acid [H3BO3] and magnesium Polyvinyl chloride (PVC) and PVC/alumina trihydrate hydroxide $\left[\mathrm{Mg}(\mathrm{OH})_{2}\right]$. Results showed that flashover (ATH) composites samples have been prepared and voltage values increase for samples containing ATH filler exposed to various degrees of temperatures to study their than that of samples containing $\mathrm{H} 3 \mathrm{BO} 3$ and $\mathrm{Mg}(\mathrm{OH})_{2}$ fillers at all percentages of filler concentrations [1].

effect on the performance of these composites as insulating materials [6].

Measurements of the ac breakdown strength of Titanium dioxide (TiO2), silica (SiO2) fillers with nanocomposites with different filler loadings of $0.1,1$ and different concentrations and different size were added to $5 \mathrm{wt} \%$ were performed to study the effect of samples thickness on the ac breakdown strength of nanocomposites and to study the effect of the filler type on the breakdown strength. It is observed that the ac breakdown strength values decrease for $0.1 \mathrm{wt} \%$ and $1 \mathrm{wt} \%$ filler concentrations and increased at $5 \mathrm{wt} \%$ filler concentration as in comparison to the unfilled epoxy [2].

A study on polymer composites that are used in highvoltage was analysed to determine the impact of filler size, type on the properties of the polymer composites compared to the unfilled polymer. It was concluded that the use of polymer composites in electrical engineering is very promising [3]. Epoxy to improve the performance, maximize dielectric strength and increase the electrical strength [7].

Flashover voltage $(\mathrm{kV})$ of polyester composite was measured at different environmental conditions and polyester composite samples with different concentrations of mica filler have been prepared, this is to improve the electrical and mechanical properties in addition to maximize the surface flashover voltage [8].

Measurements have been performed for flashover voltage $(\mathrm{kV})$ evaluating of Silicone rubber / Ethylene propylene dienemonoemer blends of outdoor insulators as effect of desert environmental conditions on the electrical performance of polymer materials has been studied [9]. 


\section{International Journal of Innovative Research in Electrical, Electronics, Instrumentation and Control Engineering}

\section{ISO 3297:2007 Certified}

Vol. 5, Issue 2, February 2017

$\mathrm{AC}$ and DC Flashover Voltages of Polyvinyl Chloride Insulating Material have been evaluated. AC and DC voltages have been measured for different samples at different temperatures. Also, the effect of Alumina trihydrate (ATH) filler with various concentrations on the constitution of polyvinyl chloride material has been studied [10].

\section{EXPERIMENTAL WORK}

A single-phase high voltage transformer (100KV -5 KVA) is used to obtain the AC high voltage. (0-220V)variac regulating panel is used to smoothly control the output voltage of the transformeras shown in Fig.1. The voltage applied to the transformer primary winding. The power supply was connected across two electrodes. Samples have been prepared from unsaturated polyester and they were fabricated as cylindrical rods having $12 \mathrm{~mm}$ diameter. Fig.2, Fig3 show ATH and Mica Powder fillers that have been added to unsaturated polyester.Fig.4, Fig.5 show the final shapes of unsaturated polyester insulators after being chemically prepared.

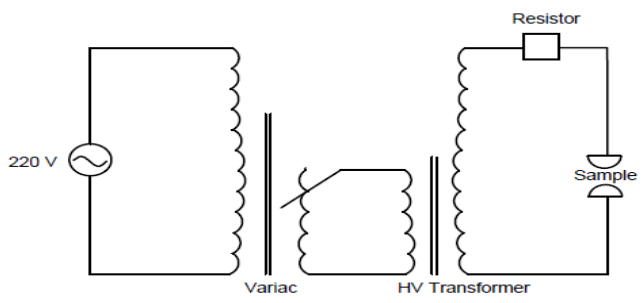

Fig.1.Single-phase high voltage transformer

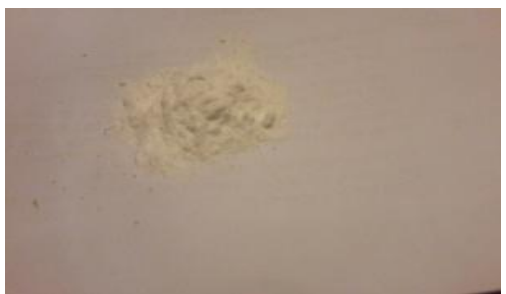

Fig.2. ATHpowder filler

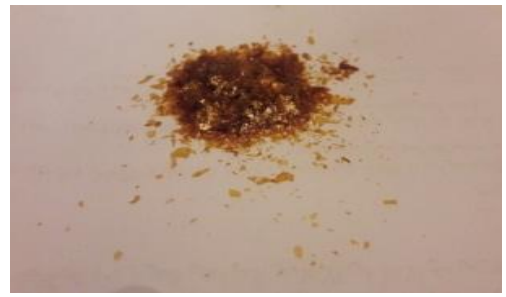

Fig.3.Micapowder filler

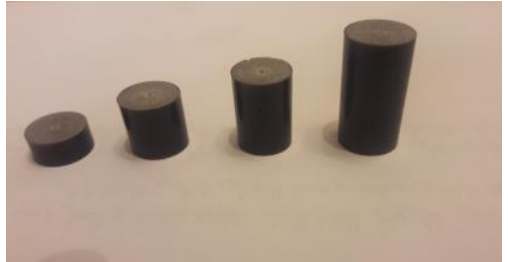

Fig.4.Unsaturated polyester insulator with mica filler

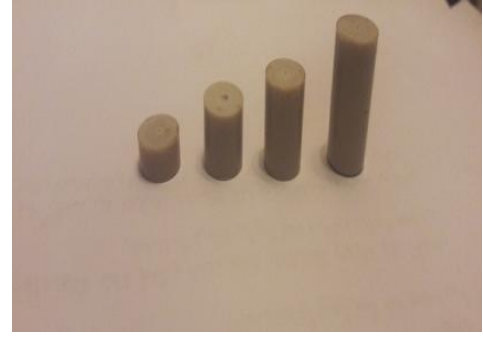

Fig.5.Unsaturated polyester insulator with ATH filler

\section{RESULTS AND DISCUSSION}

A. Flashover voltage study of dry unsaturated polyester with ATH and mica Fillers

The flashover voltage values of unsaturated polyester without fillers and with different fillers of mica and ATH at different lengths of $0.5 \mathrm{~cm}, 1 \mathrm{~cm}, 1.5 \mathrm{~cm}$ and $2 \mathrm{~cm}$ at dry condition were measured and are shown in Fig.6, Fig.7 respectively.

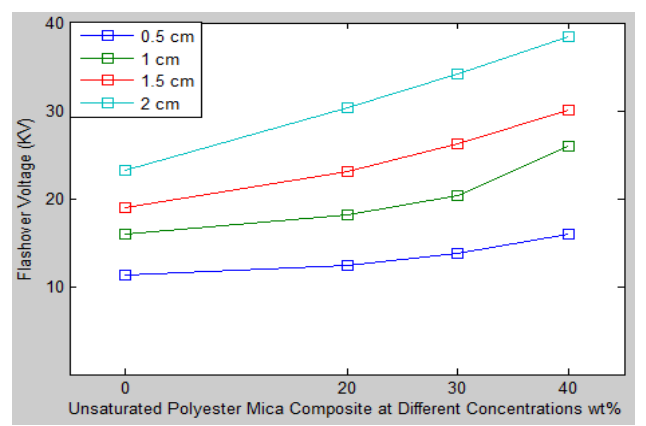

Fig.6. Flashover voltage of dry unsaturated polyester with mica filler at different concentrations

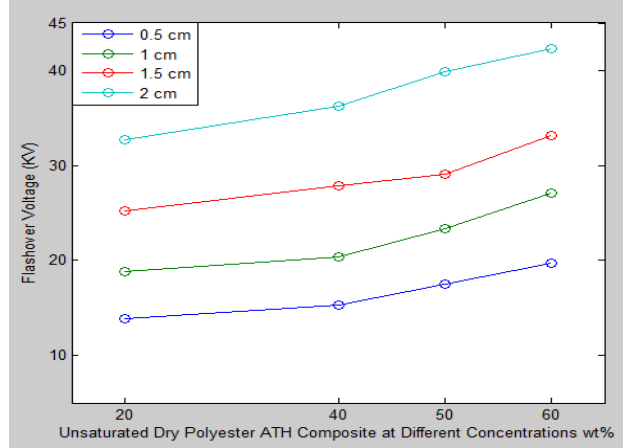

Fig.7. Flashover voltage of dry unsaturated polyester with ATH filler at different concentrations

It is observed that the flashover voltage values of $20 \mathrm{wt} \%$ filler concentration decrease for ATH and mica fillers at all lengths of samples. With an increase in the filler concentration to $40 \mathrm{wt} \%$, the flashover voltage values increase. It can be seen from Fig.6, Fig.7 that the increase in the flashover voltage with increase in the filler concentration is more prominent at higher length of $2 \mathrm{~cm}$. For $0.5 \mathrm{~cm}, 1 \mathrm{~cm}, 1.5 \mathrm{~cm}$ length samples, the flashover voltage increases with filler concentration increase but not as much as in the case of $2 \mathrm{~cm}$ sample length. 
Vol. 5, Issue 2, February 2017

Weibull distribution has been used to study the probability of flashover voltage to occur of the unsaturated polyester with different fillers [11-15]. The shape parameter $\beta$ is a range measure of the failure in term of voltage and the scale parameter $\alpha$ is the flashover voltage at the cumulative failure probability. The Weibull probability plots for the samples with $0.5 \mathrm{~cm}$ and $2.0 \mathrm{~cm}$ length are shown in Fig.8,Fig.9,Fig.10and Fig.11. The shape parameter and scale parameter are shown in Tables1- 4 .

TABLE1. SHAPE PARAMETER (B) OF DRY UNSATURATED POLYESTER WITH MICA FILLER

\begin{tabular}{|l|c|c|c|c|}
\hline \multirow{2}{*}{$\begin{array}{c}\text { Sample } \\
\text { Length } \\
(\mathbf{c m})\end{array}$} & \multirow{2}{*}{$\begin{array}{c}\text { Un } \\
\text { saturated } \\
\text { Polyester }\end{array}$} & \multicolumn{3}{|c|}{$\begin{array}{c}\text { Unsaturated Polyester with } \\
\text { Mica filler }\end{array}$} \\
\cline { 3 - 5 } & & $\begin{array}{c}\text { Mica } \\
\text { 20wt\% }\end{array}$ & $\begin{array}{c}\text { Mica } \\
\text { 30wt\% }\end{array}$ & $\begin{array}{c}\text { Mica } \\
\text { 40wt\% }\end{array}$ \\
\hline 0.5 & 12.1703 & 19.0369 & 16.7892 & 21.7853 \\
\hline 2 & 35.7113 & 32.4099 & 47.7203 & 51.9821 \\
\hline
\end{tabular}

TABLE2. SCALE PARAMETER (A) OF DRY UNSATURATED POLYESTER WITH MICA FILLER

\begin{tabular}{|l|l|c|c|c|}
\hline \multirow{2}{*}{$\begin{array}{c}\text { Sample } \\
\text { Length } \\
(\mathbf{c m})\end{array}$} & \multirow{2}{*}{$\begin{array}{c}\text { Un } \\
\text { saturated } \\
\text { Polyester }\end{array}$} & \multicolumn{3}{|c|}{$\begin{array}{c}\text { Unsaturated Polyester with } \\
\text { Mica filler }\end{array}$} \\
\cline { 3 - 5 } & & $\begin{array}{c}\text { Mica } \\
\text { 20wt\% }\end{array}$ & $\begin{array}{c}\text { Mica } \\
\text { 30wt\% }\end{array}$ & $\begin{array}{c}\text { Mica } \\
\text { 40wt\% }\end{array}$ \\
\hline 0.5 & 10.6975 & 11.9278 & 12.7305 & 13.7019 \\
\hline 2 & 21.7936 & 28.9642 & 31.6215 & 44.6259 \\
\hline
\end{tabular}

TABLE3. SHAPE PARAMETER (B) OF DRY UNSATURATED POLYESTER WITH ATH FILLER

\begin{tabular}{|l|c|c|c|c|}
\hline \multirow{2}{*}{$\begin{array}{c}\text { Sample } \\
\text { Length } \\
(\mathbf{c m})\end{array}$} & \multicolumn{4}{|c|}{ Unsaturated Polyester with ATH filler } \\
\cline { 2 - 5 } & $\begin{array}{c}\text { ATH } \\
\mathbf{2 0 w t} \%\end{array}$ & $\begin{array}{c}\text { ATH } \\
\mathbf{4 0 w t} \%\end{array}$ & $\begin{array}{c}\text { ATH } \\
\mathbf{5 0 w t} \%\end{array}$ & $\begin{array}{c}\text { ATH } \\
\mathbf{6 0 w t} \%\end{array}$ \\
\hline 0.5 & 14.5007 & 14.1889 & 11.8428 & 12.2619 \\
\hline 2 & 28.7889 & 33.3356 & 29.179 & 43.5462 \\
\hline
\end{tabular}

TABLE4. SCALE PARAMETER (A) OF DRY UNSATURATED POLYESTER WITH ATH FILLER

\begin{tabular}{|l|c|c|c|c|}
\hline \multirow{2}{*}{$\begin{array}{c}\text { Sample } \\
\text { Length }\end{array}$} & \multicolumn{4}{|c|}{ Unsaturated Polyester with ATH filler } \\
\cline { 2 - 5 } (cm) & $\begin{array}{c}\text { ATH } \\
\mathbf{2 0 w t} \%\end{array}$ & $\begin{array}{c}\text { ATH } \\
\mathbf{4 0 w} \%\end{array}$ & $\begin{array}{c}\text { 50wt \% } \\
\text { 50wt }\end{array}$ & $\begin{array}{c}\text { ATH } \\
\mathbf{6 0 w t} \%\end{array}$ \\
\hline 0.5 & 14.0199 & 15.7571 & 18.5699 & 19.7249 \\
\hline 2 & 33.1236 & 37.1689 & 40.0075 & 43.0574 \\
\hline
\end{tabular}

It is observed from Tables 1, 3 that the shape parameter $\beta$ increases with the addition of fillers to unsaturated polyester. The $\beta$-parameter showed an increase with increasing lengths for unsaturated polyester as well as unsaturated polyester with mica and ATH fillers for all the filler concentrations considered. With the increase in the lengths of the samples, the flashover voltage $(\alpha)$ increases both unsaturated polyester as well as unsaturated polyester with mica and ATH fillers as shown in Tables 2,4.

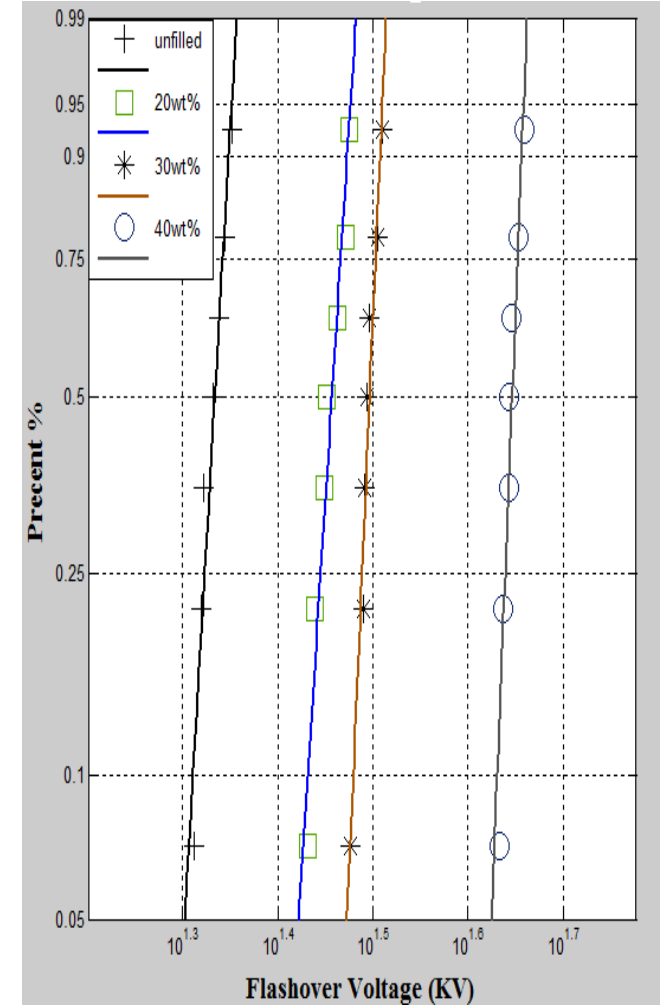

Fig.8. Weibull probability plot of dry unsaturated polyester with mica filler of $0.5 \mathrm{~cm}$ length

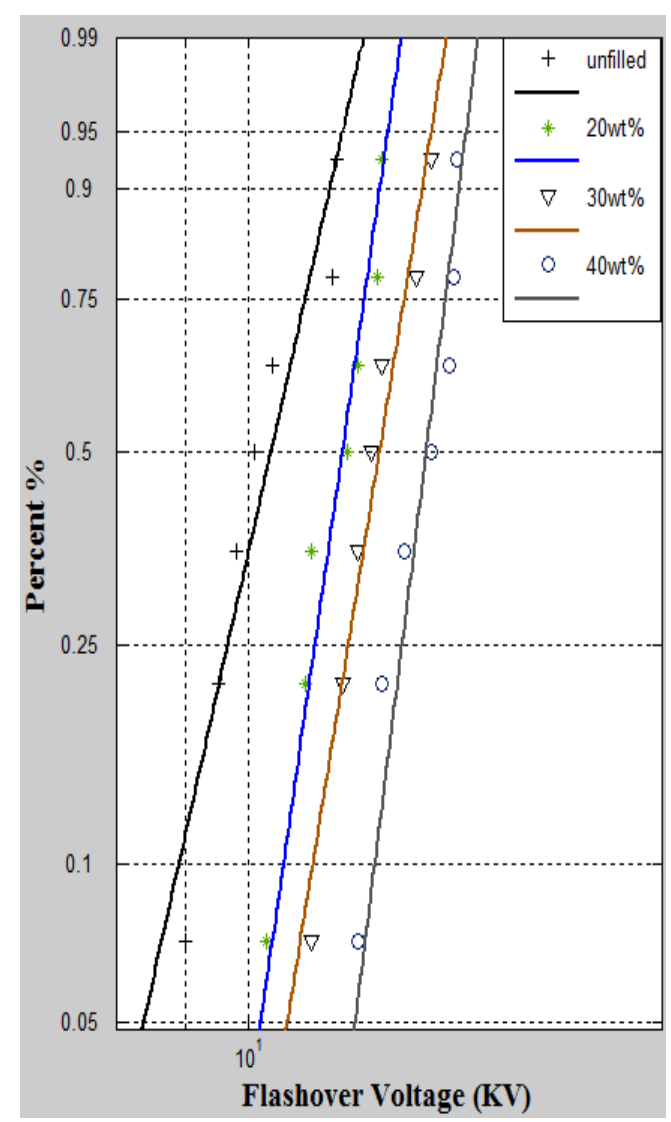

Fig.9. Weibull probability plot of dry unsaturated polyester with mica filler of $2.0 \mathrm{~cm}$ length 
Vol. 5, Issue 2, February 2017

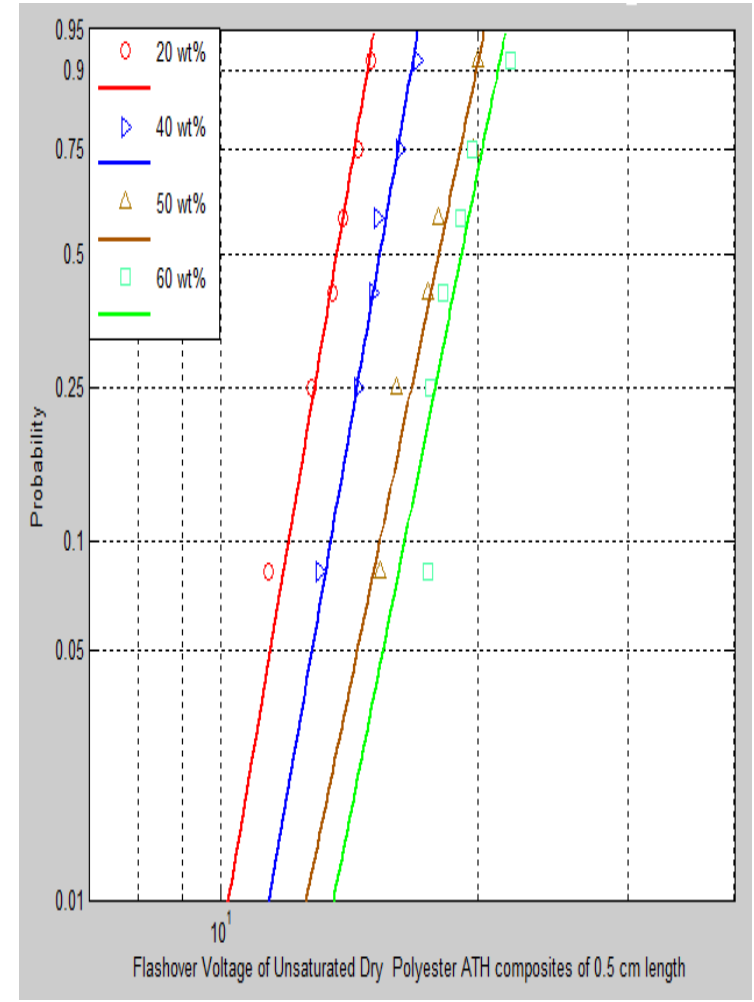

Fig.10. Weibull probability plot of dry unsaturated polyester with ATH filler of $0.5 \mathrm{~cm}$ length

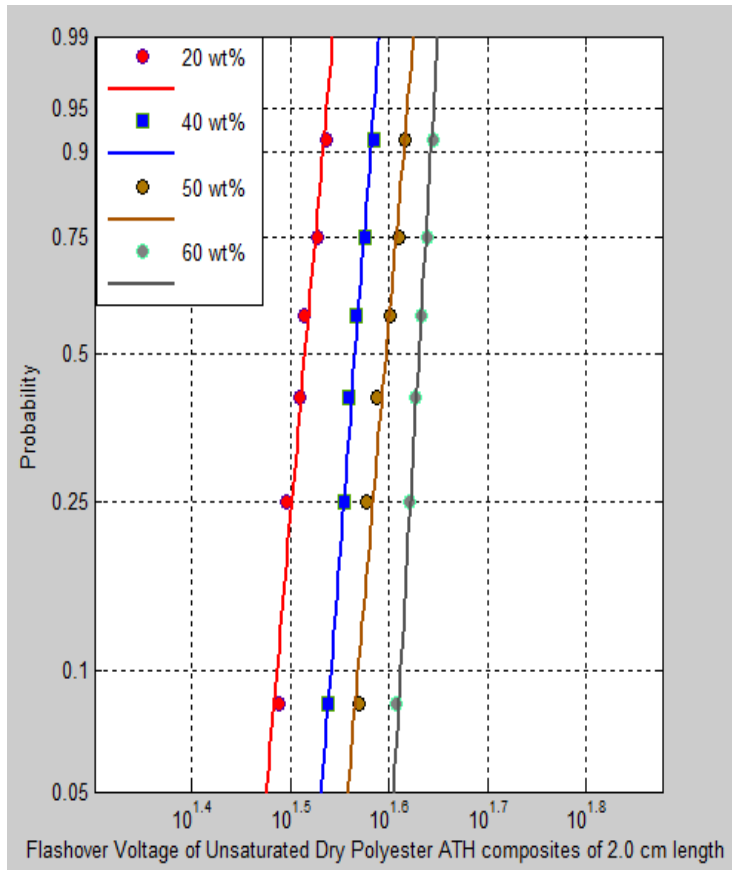

Fig.11. Weibull probability plot of dry unsaturated polyester with ATH filler of $2 \mathrm{~cm}$ length

B. Flashover voltage study of wet unsaturated polyester with ATH and mica Fillers

The flashover voltage values of unsaturated polyester without fillers and with different fillers of mica and ATH at different lengths of $0.5 \mathrm{~cm}, 1 \mathrm{~cm}, 1.5 \mathrm{~cm}$ and $2 \mathrm{~cm}$ at wet condition were measured and are shown in Fig.12, Fig.13 respectively.

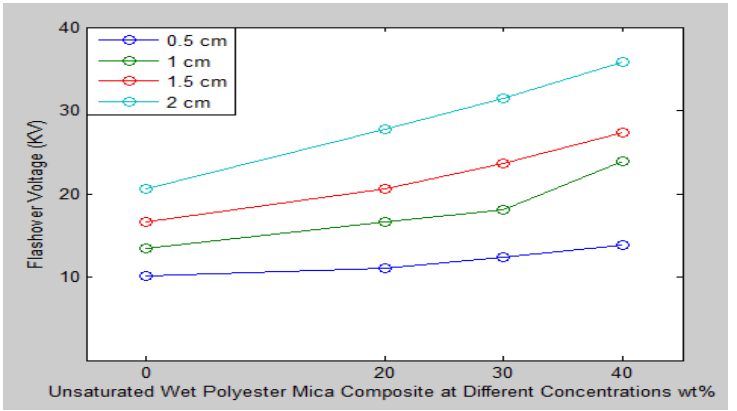

Fig.12. Flashover voltage of wet unsaturated polyester with mica filler at different filler concentrations

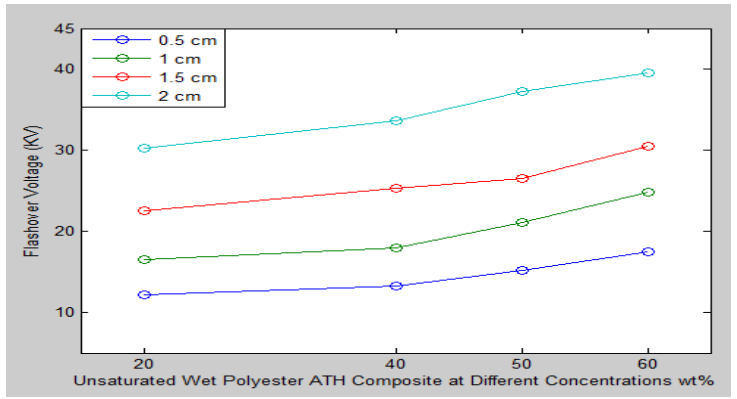

Fig.13. Flashover voltage of wet unsaturated polyester with ATH filler at different filler concentrations

It is noted from Tables 6,8 that the flashover voltage $(\alpha)$ decreases in all wet unsaturated polyester with ATH and mica fillers into comparison with all values of dry unsaturated polyester with ATH and mica fillers. This is due to flow of leakage current in unsaturated polyester that increases the opportunity of flashover to occur. The weibull probability plots for the samples with $0.5 \mathrm{~cm}$ and $2.0 \mathrm{~cm}$ length are shown in Fig.14, Fig.15, Fig.16and Fig.17. The shape parameter and scale parameter are shown in Tables 5- 8 .

TABLE5. SHAPE PARAMETER (B) OF WET UNSATURATED POLYESTER WITH MICA FILLER

\begin{tabular}{|l|l|l|c|}
\hline \multirow{2}{*}{$\begin{array}{c}\text { Sample } \\
\text { Length } \\
(\mathbf{c m})\end{array}$} & \multicolumn{3}{|c|}{ Unsaturated Polyester with Mica filler } \\
\cline { 2 - 4 } & Mica20wt\% & Mica30wt\% & Mica40wt\% \\
\hline 0.5 & 11.6832 & 10.4722 & 12.6084 \\
\hline 2 & 36.4347 & 28.3666 & 46.9241 \\
\hline
\end{tabular}

TABLE6. SCALE PARAMETER (A) OF WET UNSATURATED POLYESTER WITH MICA FILLER

\begin{tabular}{|l|l|l|l|}
\hline \multirow{2}{*}{$\begin{array}{c}\text { Sample } \\
\text { Length } \\
(\mathbf{c m})\end{array}$} & \multicolumn{3}{|c|}{ Unsaturated Polyester with Mica filler } \\
\cline { 3 - 4 } & Mica20wt\% & Mica30wt\% & Mica40wt\% \\
\hline 0.5 & 9.49874 & 9.78961 & 9.99944 \\
\hline 2 & 22.8876 & 27.8194 & 40.6772 \\
\hline
\end{tabular}


Vol. 5, Issue 2, February 2017

TABLE7. SHAPE PARAMETER (B) OF WET UNSATURATED POLYESTER WITH ATH FILLER

\begin{tabular}{|l|c|c|c|c|}
\hline \multirow{2}{*}{$\begin{array}{c}\text { Sample } \\
\text { Length } \\
(\mathbf{c m})\end{array}$} & \multicolumn{4}{|c|}{ Unsaturated Polyester with ATH filler } \\
\cline { 2 - 5 } & $\begin{array}{c}\text { ATH } \\
\mathbf{2 0 w t} \%\end{array}$ & $\begin{array}{c}\text { ATH } \\
\mathbf{4 0 w t} \%\end{array}$ & $\begin{array}{c}\text { ATH } \\
\mathbf{5 0 w t} \%\end{array}$ & $\begin{array}{l}\text { ATH } \\
\mathbf{6 0 w t} \%\end{array}$ \\
\hline 0.5 & 9.96176 & 11.3767 & 15.4339 & 13.8047 \\
\hline 2 & 25.9934 & 25.1018 & 30.2847 & 30.6945 \\
\hline
\end{tabular}

TABLE8. SCALE PARAMETER (A) OF WET UNSATURATED POLYESTER WITH ATH FILLER

\begin{tabular}{|l|c|c|c|c|}
\hline \multirow{2}{*}{$\begin{array}{c}\text { Sample } \\
\text { Length } \\
(\mathbf{c m})\end{array}$} & \multicolumn{4}{|c|}{ Unsaturated Polyester with ATH filler } \\
\cline { 2 - 5 } & $\begin{array}{c}\text { ATH } \\
\mathbf{2 0 w t} \%\end{array}$ & $\begin{array}{c}\text { ATH } \\
\mathbf{4 0 w t} \%\end{array}$ & $\begin{array}{c}\text { ATH } \\
\mathbf{5 0 w t} \%\end{array}$ & $\begin{array}{l}\text { ATH } \\
\mathbf{6 0 w t} \%\end{array}$ \\
\hline 0.5 & 13.1939 & 14.251 & 16.1168 & 18.0866 \\
\hline 2 & 31.1072 & 34.1681 & 38.3708 & 40.1634 \\
\hline
\end{tabular}

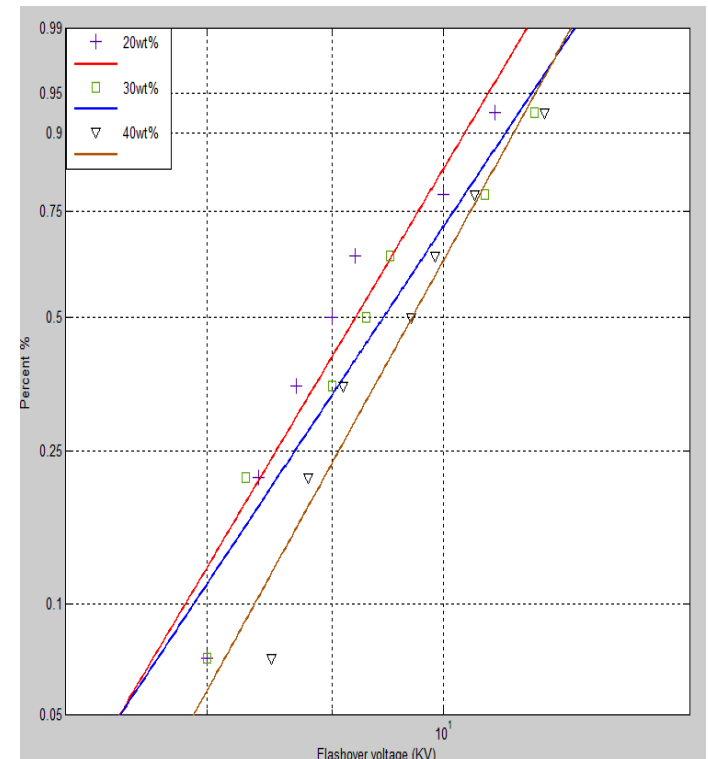

Fig.14. Weibull probability plot of wet unsaturated polyester with mica filler of $0.5 \mathrm{~cm}$ length

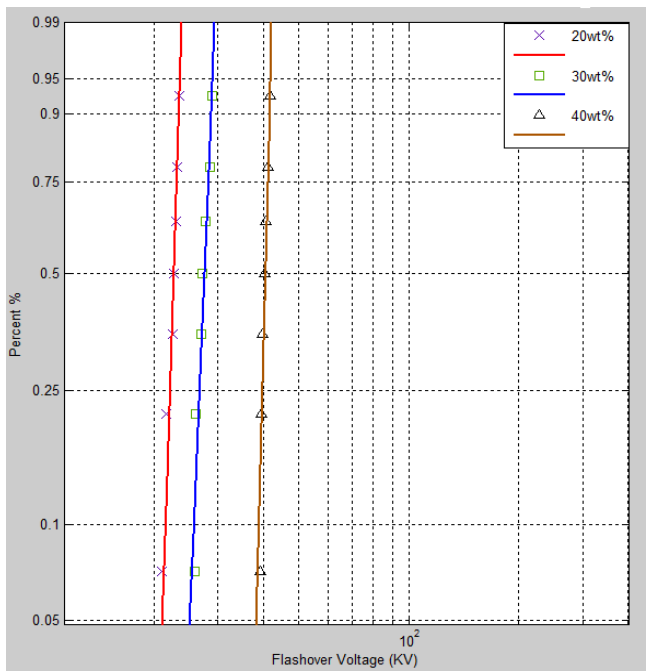

Fig.15. Weibull probability plot of wet unsaturated polyester with mica filler of $2 \mathrm{~cm}$ length

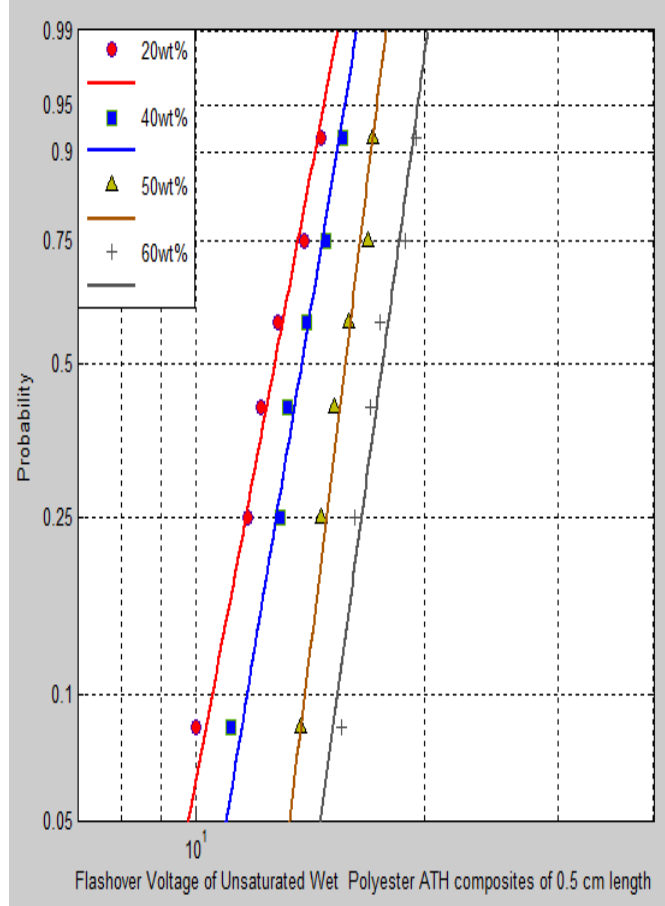

Fig.16. Weibull probability plot of wet unsaturated polyester with ATH filler of $0.5 \mathrm{~cm}$ length

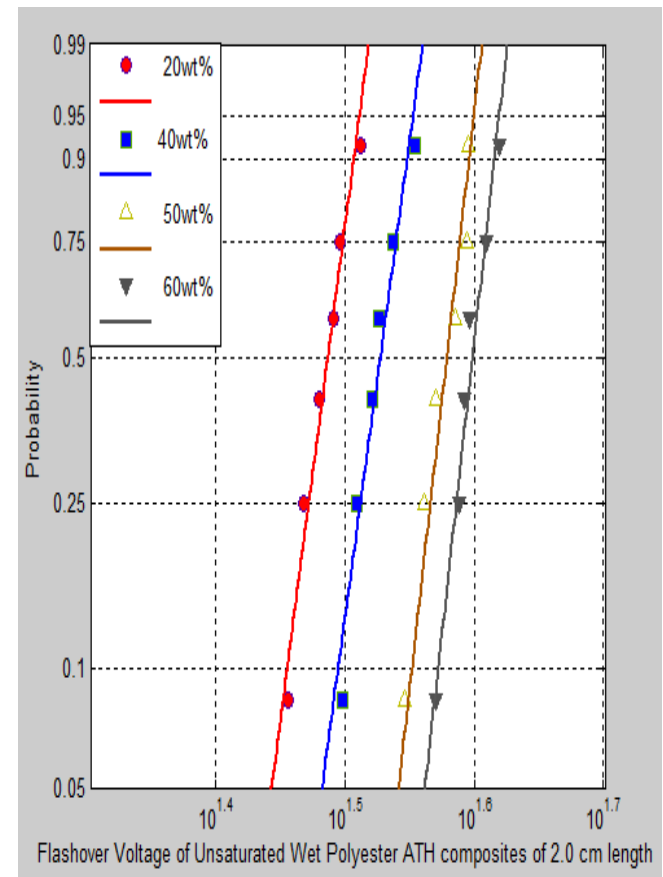

Fig.17. Weibull probability plot of wet unsaturated polyester with ATH filler of $2.0 \mathrm{~cm}$ length.

C. Flashover voltage study of sodium chloride unsaturated polyester with ATH and mica Fillers

The flashover voltage values of unsaturated polyester and with different fillers of ATH and mica at different lengths of $0.5 \mathrm{~cm}, 1 \mathrm{~cm}, 1.5 \mathrm{~cm}$ and $2 \mathrm{~cm}$ with addition of sodium chloride were measured and are shown in Fig.18, Fig.19respectively. 
International Journal of Innovative Research in Electrical, Electronics, Instrumentation and Control Engineering

ISO 3297:2007 Certified

Vol. 5, Issue 2, February 2017

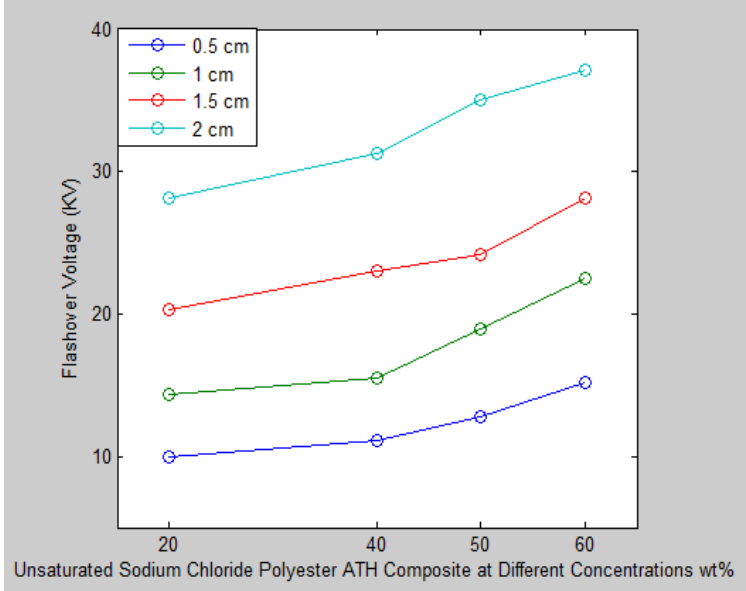

Fig.18. Flashover voltage of sodiumchloride unsaturated polyester with ATH filler at different filler concentrations

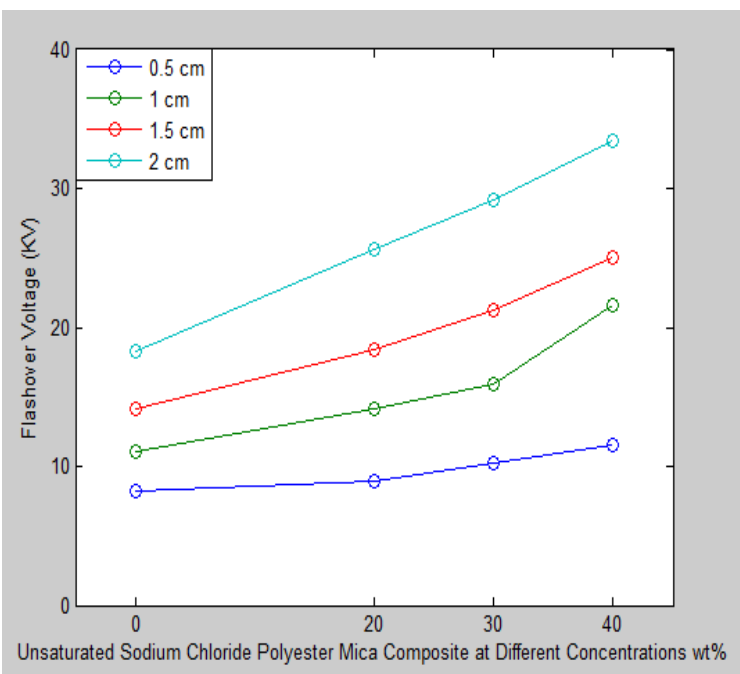

Fig.19. Flashover voltage of sodium chloride unsaturated polyester with Mica filler at different filler concentrations

With sodium chloride addition to unsaturated polyester with ATH and mica fillers, the flashover voltage $(\alpha)$ decreases into comparison with all values of dry and wet unsaturated polyester with ATH and mica fillers as shown in Tables 10,12. This is due to flow increase of leakage current between the electrodes that increase the opportunity of flashover to occur. The weibull probability plots for the samples with $0.5 \mathrm{~cm}$ and $2.0 \mathrm{~cm}$ length are shown in Fig.20, Fig.21, Fig.22 and Fig.23. The shape parameter and scale parameter are shown in Tables $9-12$.

TABLE9. SHAPE PARAMETER (B) OF SODIUM CHLORIDE UNSATURATED POLYESTER WITH MICA FILLER

\begin{tabular}{|c|l|c|c|}
\hline \multirow{2}{*}{$\begin{array}{c}\text { Sample } \\
\text { Length } \\
\text { (cm) }\end{array}$} & \multicolumn{3}{|c|}{ Unsaturated Polyester with Mica filler } \\
\cline { 2 - 4 } & $\begin{array}{c}\text { Mica } \\
\text { 20wt\% }\end{array}$ & $\begin{array}{c}\text { Mica } \\
\text { 30wt\% }\end{array}$ & $\begin{array}{c}\text { Mica } \\
\text { 40wt\% }\end{array}$ \\
\hline 0.5 & 7.60613 & 7.29261 & 8.85796 \\
\hline 2 & 24.2754 & 28.7613 & 46.2638 \\
\hline
\end{tabular}

TABLE10. SCALE PARAMETER (A) OF SODIUM CHLORIDE UNSATURATED POLYESTER WITH MICA FILLER

\begin{tabular}{|l|l|c|c|}
\hline \multirow{2}{*}{$\begin{array}{c}\text { Sample } \\
\text { Length } \\
(\mathbf{c m})\end{array}$} & \multicolumn{3}{|c|}{ Unsaturated Polyester with Mica filler } \\
\cline { 2 - 4 } & $\begin{array}{c}\text { Mica } \\
\mathbf{2 0 w t \%}\end{array}$ & $\begin{array}{c}\text { Mica } \\
\mathbf{3 0 w t} \%\end{array}$ & $\begin{array}{c}\text { Mica } \\
\mathbf{4 0 w t} \%\end{array}$ \\
\hline 0.5 & 6.64819 & 7.63829 & 7.80558 \\
\hline 2 & 19.6826 & 25.8529 & 37.9379 \\
\hline
\end{tabular}

TABLE11. SHAPE PARAMETER (B) OF SODIUM CHLORIDE UNSATURATED POLYESTER WITH ATH FILLER

\begin{tabular}{|c|c|c|c|c|}
\hline \multirow{2}{*}{$\begin{array}{c}\text { Sample } \\
\text { Length } \\
(\mathbf{c m})\end{array}$} & \multicolumn{4}{|c|}{ Unsaturated Polyester with ATH filler } \\
\cline { 2 - 5 } & $\begin{array}{c}\text { ATH } \\
\mathbf{2 0 w t} \%\end{array}$ & $\begin{array}{c}\text { ATH } \\
\mathbf{4 0 w t} \%\end{array}$ & $\begin{array}{c}\text { ATH } \\
\mathbf{5 0 w t} \%\end{array}$ & $\begin{array}{c}\text { ATH } \\
\mathbf{6 0 w t} \%\end{array}$ \\
\hline 0.5 & 7.88516 & 10.7597 & 8.13872 & 15.1459 \\
\hline 2 & 26.1557 & 28.505 & 28.5651 & 27.0507 \\
\hline
\end{tabular}

TABLE12. SCALE PARAMETER (A) OF SODIUM CHLORIDE UNSATURATED POLYESTER WITH ATH FILLER

\begin{tabular}{|c|c|c|c|c|}
\hline \multirow{2}{*}{$\begin{array}{c}\text { Sample } \\
\text { Length } \\
\text { (cm) }\end{array}$} & \multicolumn{4}{|c|}{ Unsaturated Polyester with ATH filler } \\
\hline & $\begin{array}{c}\text { ATH } \\
20 w t \%\end{array}$ & $\begin{array}{c}\text { ATH } \\
40 w t \%\end{array}$ & $\begin{array}{c}\text { ATH } \\
50 w t \%\end{array}$ & $\begin{array}{c}\text { ATH } \\
\text { 60wt\% }\end{array}$ \\
\hline 0.5 & 10.6107 & 12.0139 & 12.946 & 15.9735 \\
\hline 2 & 29.0282 & 32.135 & 36.022 & 37.8716 \\
\hline
\end{tabular}

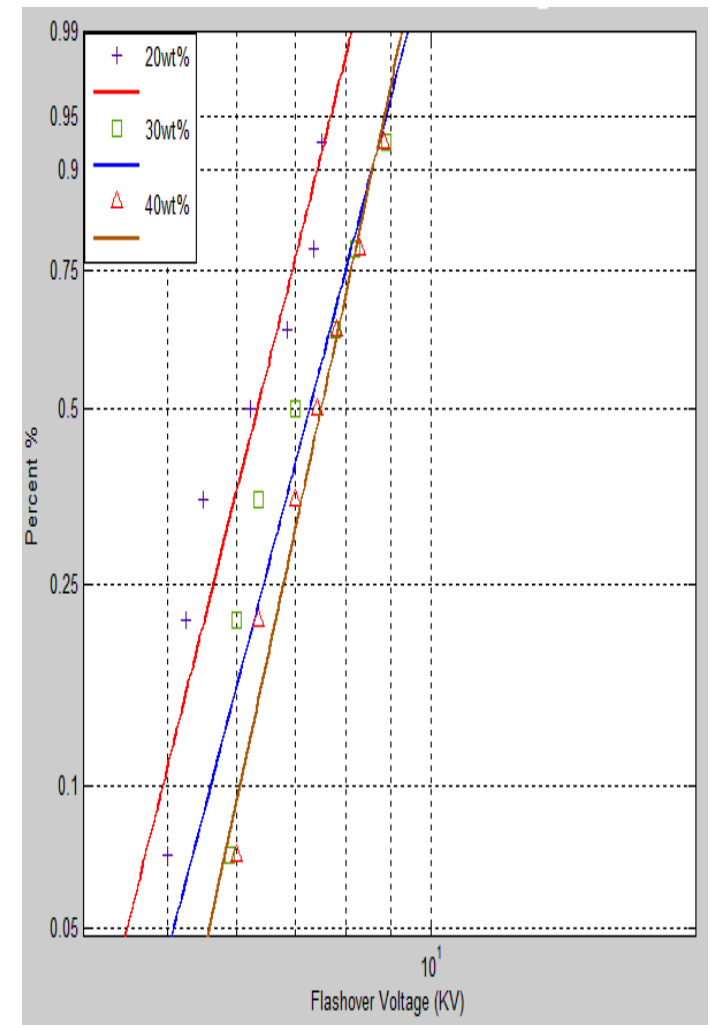

Fig.20. Weibull probability plot of sodiumchloride unsaturated polyester with mica filler of $0.5 \mathrm{~cm}$ length 
Vol. 5, Issue 2, February 2017

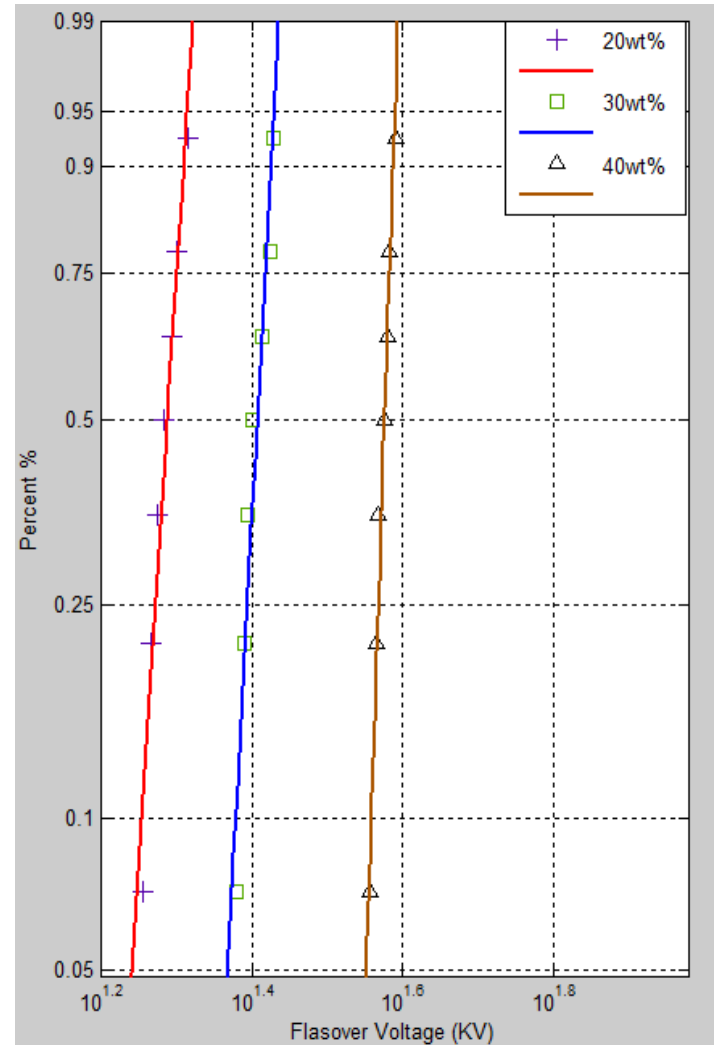

Fig.21. Weibull probability plot of sodiumchloride unsaturated polyester with mica filler of $2.0 \mathrm{~cm}$ length

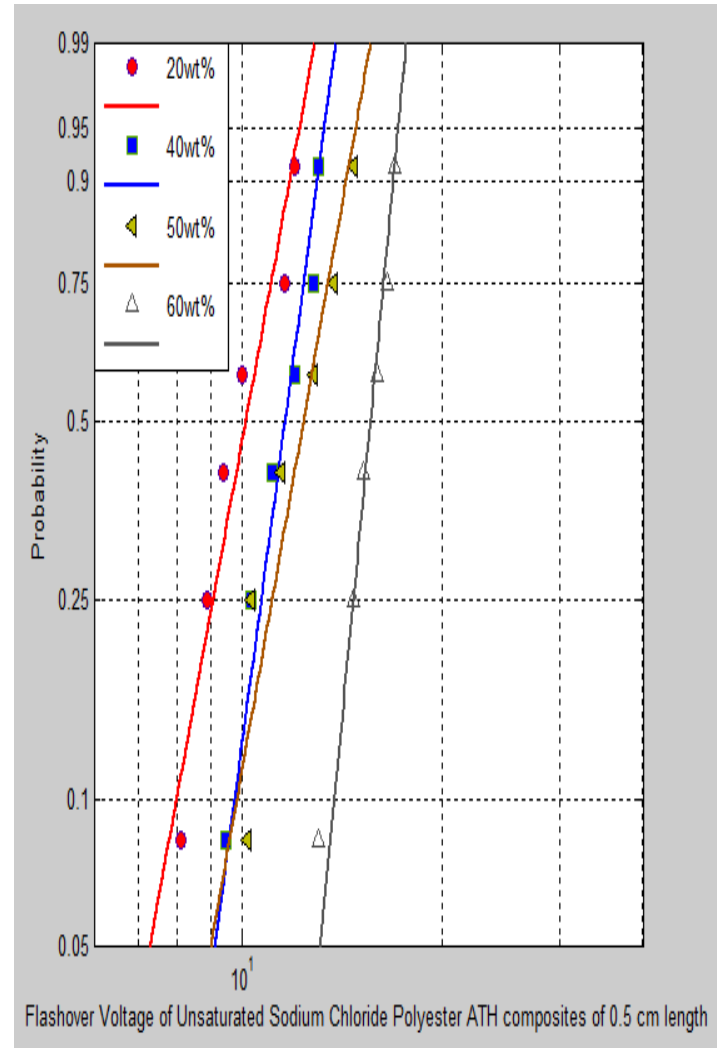

Fig.22. Weibull probability plot of sodiumchloride unsaturated polyester with ATH filler of $0.5 \mathrm{~cm}$ length

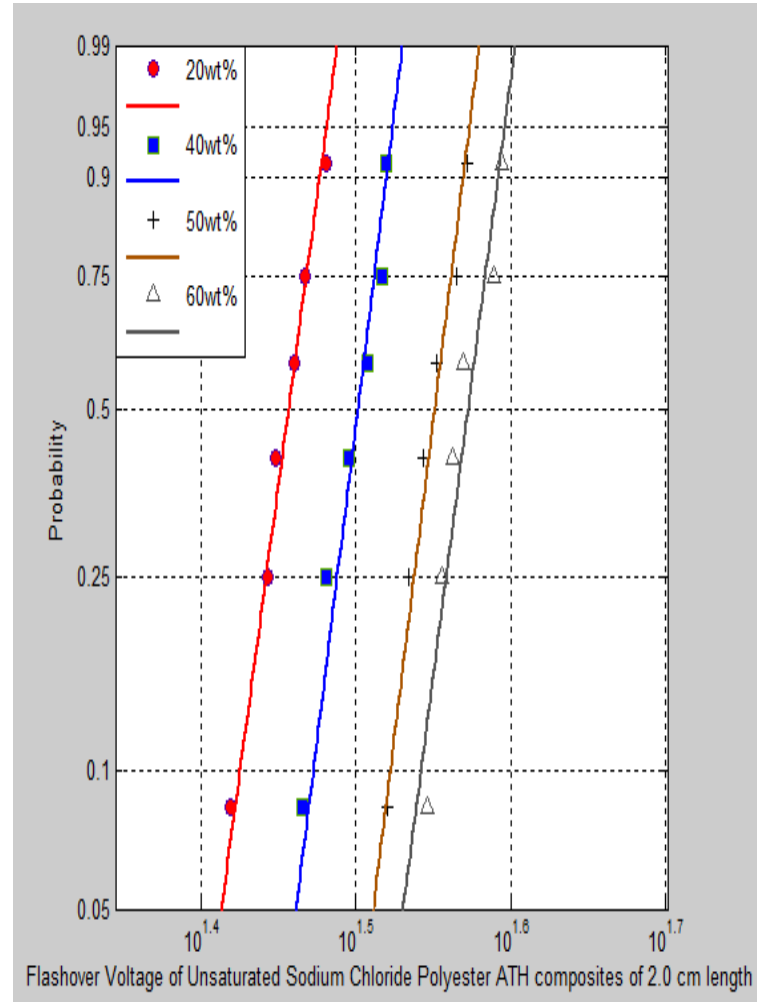

Fig.23. Weibull probability plot of sodium chloride unsaturated polyester with ATH filler of $2.0 \mathrm{~cm}$ length

\section{IV.CONCLUSION}

- At dry condition, the value of flashover voltage at which the probability of flashover reached $100 \%$ increase with increasing the percentage of fillers concentrations. At $0.5 \mathrm{~cm}$ sample length they were $13.2,13.7,14.8,15.4 \mathrm{KV}$ at unsaturated polyester , $20 \mathrm{wt} \%, 30 \mathrm{wt} \%, 40 \mathrm{wt} \%$ mica filler addition respectively and $16.7, \quad 18.8, \quad 22.9, \quad 24.2 \mathrm{KV}$ at $20 \mathrm{wt} \%, 40 \mathrm{wt} \%, 50 \mathrm{wt} \%, 60 \mathrm{wt} \%$ ATH filler addition respectively. At $2.0 \mathrm{~cm}$ sample length the values of flashover voltages at which the probability of flashover reached $100 \%$ increase into comparison with all values of $0.5 \mathrm{~cm}$ sample length. They were 23.4, 31.3, 33.4, 46.9 $\mathrm{KV}$ at unsaturated polyester , $20 \mathrm{wt} \%, 30 \mathrm{wt} \%, 40 \mathrm{wt} \%$ mica filler addition respectively and $36.2, \quad 40.1 \quad 43.6, \quad 45.7 \quad$ at $20 \mathrm{wt} \%, 40 \mathrm{wt} \%, 50 \mathrm{wt} \%, 60 \mathrm{wt} \%$ ATH filler addition respectively.

- At wet condition, the values of flashover voltage at which the probability of flashover reached $100 \%$ decrease into comparison with all values of dry condition. At $0.5 \mathrm{~cm}$ sample length they were 11.8, $12.5,12.2 \mathrm{KV}$ at $20 \mathrm{wt} \%, 30 \mathrm{wt} \%, 40 \mathrm{wt} \%$ mica filler addition respectively and $16.9,17.8,19,21.7 \mathrm{KV}$ at $20 \mathrm{wt} \%, 40 \mathrm{wt} \%, 50 \mathrm{wt} \%, 60 \mathrm{wt} \%$ ATH filler addition respectively. At $2.0 \mathrm{~cm}$ sample length they were 24.6, $30.4,42.9 \mathrm{KV}$ at $20 \mathrm{wt} \%, 30 \mathrm{wt} \%, 40 \mathrm{wt} \%$ mica filler addition respectively and $34.3,37.8,41.7,43.6 \mathrm{KV}$ at 
Vol. 5, Issue 2, February 2017

20wt $\%, 40 \mathrm{wt} \%, 50 \mathrm{wt} \%, 60 \mathrm{wt} \%$ ATH filler addition respectively.

- With sodium chloride addition, the values of flashover voltage at which the probability of flashover reached $100 \%$ decrease into comparison with all values of dry and wet conditions. At $0.5 \mathrm{~cm}$ sample length they were $9.3,10.8,10.4 \mathrm{KV}$ at $20 \mathrm{wt} \%, 30 \mathrm{wt} \%, 40 \mathrm{wt} \%$ mica filler addition respectively and $14.6,15.2,17.7,18.9$ at $20 \mathrm{wt} \%, 40 \mathrm{wt} \%, 50 \mathrm{wt} \%, 60 \mathrm{wt} \%$ ATH filler addition respectively. At $2.0 \mathrm{~cm}$ sample length they were 21.9, $28.3,40.1 \mathrm{KV}$ at $20 \mathrm{wt} \%, 30 \mathrm{wt} \%, 40 \mathrm{wt} \%$ mica filler addition respectively and $32,35.1,39.4,41.6 \mathrm{KV}$ at $20 \mathrm{wt} \%, 40 \mathrm{wt} \%, 50 \mathrm{wt} \%, 60 \mathrm{wt} \%$ ATH filler addition respectively.

- Flashover voltages of unsaturated polyester with ATH and mica fillers at different weather conditions are shown in Fig.24,Fig.25 and Fig.26.

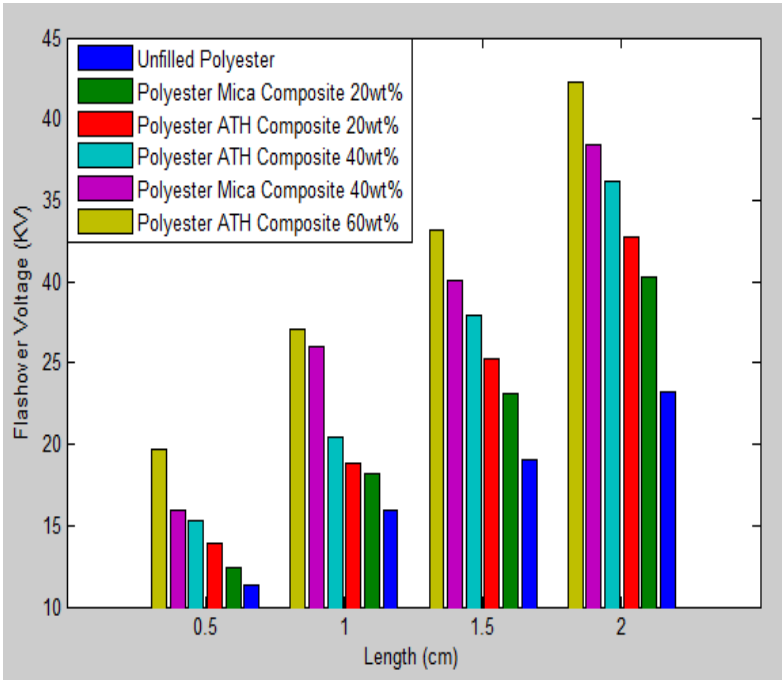

Fig.24. Flashover voltage of dry unsaturated polyester with ATH and mica fillers

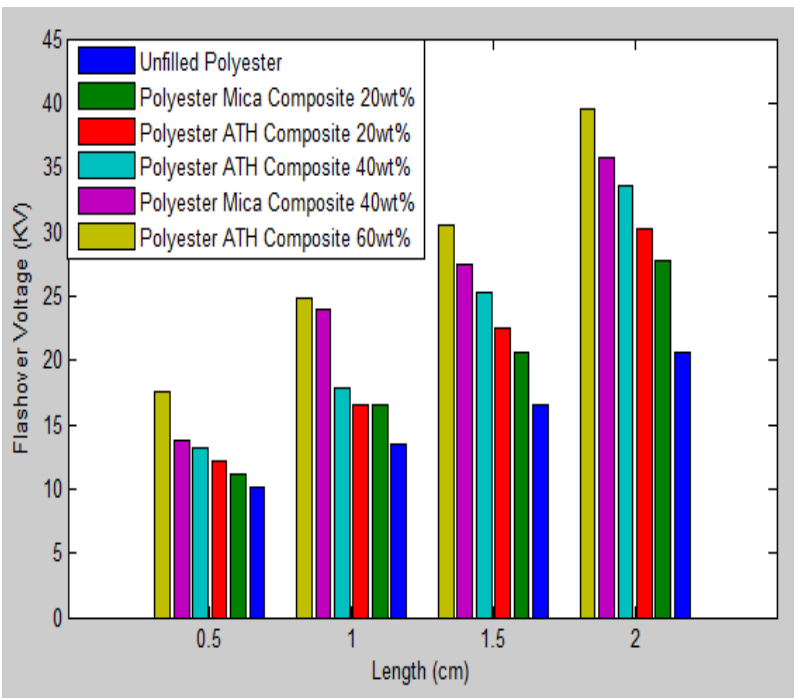

Fig.25. Flashover voltage of wet unsaturated polyester with ATH and mica fillers

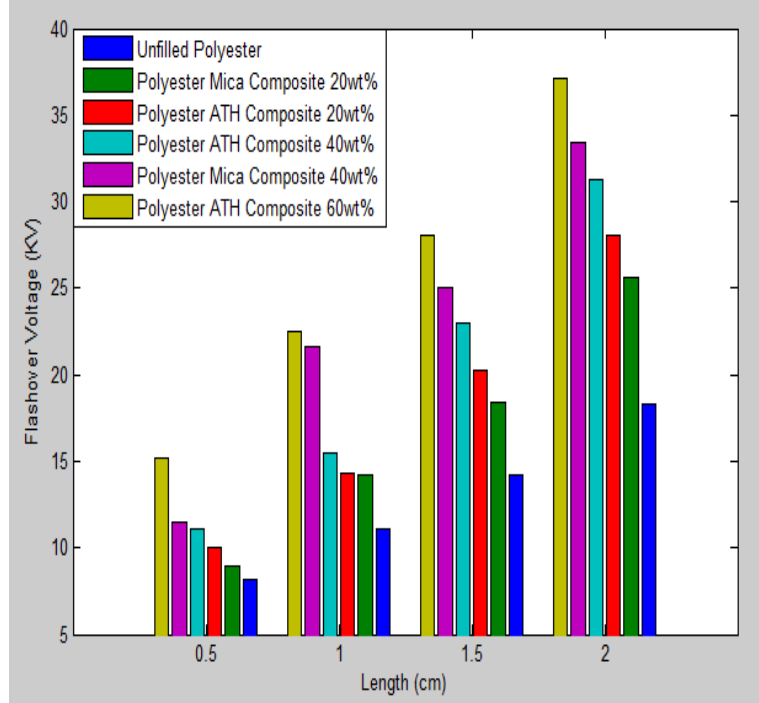

Fig.26. Flashover voltage of sodium chloride unsaturated polyester with ATH and mica fillers

\section{ACKNOWLEDGMENT}

I would like to express my honest gratitude to Professor El-Said Othman and Professor Loai Nasrat for the continuous guidance, support and encouragement they have provided throughout my Ph.D. studies.

\section{REFERENCES}

[1] L.S. Nasrat, A.F. Hamed, M.A. Hamid, S.H. Mansour, Study the flashover voltage for outdoor polymer insulators under desert climatic conditions, Egyptian Journal of Petroleum, Volume 22, Issue 1, June 2013, Pages 1-8, ISSN 1110-0621, http://dx.doi.org/10.1016/j.ejpe.2012.11.011.

[2] Preetha, P., and M. Joy Thomas. "AC breakdown characteristics of epoxy nanocomposites." IEEE Transactions on Dielectrics and Electrical Insulation 18.5 (2011).

[3] Pleşa, Ilona, et al. "Properties of Polymer Composites Used in High-Voltage Applications." Polymers 8.5 (2016): 173.

[4] L.S.Nasrat, A.M.Eid "Effect of Two Decades Aging on the Ultrasonic and Electrical Properties of Polymer Composite Materials." Journal of Electrical Engineering.

[5] Nasrat, L. S., M. Hamed, and A. A. Ibrahim. "Effect of ultra violet on dry band arcing behavior of EPDM outdoor insulators." Int J EmergTechnolAdvEng 4.10 (2014): 1-8.

[6] Nasrat, L. S., et al. "Ac and DC flashover voltages of polyvinyl chloride insulating material." Electrical, Electronic and Computer Engineering, 2004. ICEEC'04. 2004 International Conference on. IEEE, 2004

[7] Abdelkarim, M. F., et al. "Effect of nano fillers on electrical performance of epoxy composite insulators." International Journal of Engineering and Technical Research 2.7 (2014): 60-65.

[8] Nasrat, Loai, et al. "Mica Filler Effect on Electrical Characteristics of Polymer Insulators." International Journal of Engineering Innovations and Research 5.2 (2016): 168.

[9] Nasrat, L. S., A. A. Ibrahim, and H. A. Mortadda. "Effect of Environmental Desert Conditions on the Performance of Hydrophobic Polymer Insulators Surfaces." International Journal of Emerging Technology and Advanced Engineering" (ISSN 22502459, ISO 9001:2008 Certified Journal, Volume 4, Issue 12, December 2014). 
Vol. 5, Issue 2, February 2017

[10] Nasrat, L. S., et al. "Ac and DC flashover voltages of polyvinyl chloride insulating material." Electrical, Electronic and Computer Engineering, 2004. ICEEC'04. 2004 International Conference on. IEEE, 2004.

[11] Rinne, H., The Weibull Distribution A Handbook. 2009, USA: CRC Press,Taylor and Francis Group.

[12] IEC/IEEE Guide for the Statistical Analysis of Electrical Insulation Breakdown Data (Adoption of IEEE Std 930-2004). IEC 62539 First Edition2007-07 IEEE 930, 2007: p. 1-53.

[13] Wang, Qi. The effect of nano size fillers on electrical performance of epoxy resin. Diss. University of Southampton, 2012.

[14] Abernethy, Robert B., et al. Weibull analysis handbook. No. PWA/GPD-FR-17579. PRATT AND WHITNEY WEST PALM BEACH FL GOVERNMENT PRODUCTS DIV, 1983.

[15] Abernethy, Robert B. The new Weibull handbook. Dr. Robert B. Abernethy, 2006.

\section{BIOGRAPHIES}

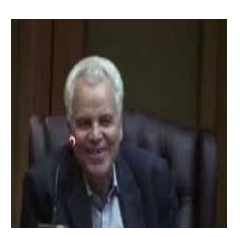

Prof. Dr. El-said Othmanis professorat Electrical Power and Machine Department, Faculty of Engineering, Alazhar University. He received the B.Sc., M.Sc. and Ph.D. degrees from Alazhar University.

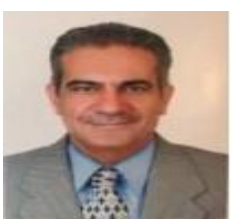

Prof. Dr. LoaiNasratis professorat Electrical Power and Machine Department, Faculty of Engineering, Aswan University. He received the B.Sc., M.Sc. and Ph.D. degrees from Ainshams University.

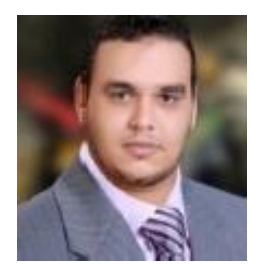

Eng. Abdelrahman A. Z. Salehis Ph.D. researcher at Electrical Power and Machine Department, Faculty of Engineering, Alazhar University. He receivedthe B.Sc. in Electrical Engineering from Benha University and M.Sc. from Alazhar University. 